\title{
Report on Four Species of Crabs (Crustacea: Decapoda: Brachyura) from Korea
}

\author{
Sang-kyu Lee ${ }^{1}$, Sa Heung $\mathrm{Kim}^{2}$ and Won Kim ${ }^{1, *}$ \\ ${ }^{1}$ School of Biological Sciences, Seoul National University, Seoul 151-747, Korea \\ ${ }^{2}$ Laboratory of Marine Biodiversity, IN THE SEA KOREA Co. Ltd., Seogwipo 697-110, Korea
}

\begin{abstract}
One pilumnoid, Neoactumnus convexus Sakai, 1965, and three xanthoids, Lybia caestifera (Alcock, 1898), Atergatopsis germaini A. Milne-Edwards, 1865, and Platypodia tomentosa (De Man, 1902), are newly recorded in Korean fauna. Korean pilumnoids and xanthoids now consist of fifteen species and twenty species, respectively.
\end{abstract}

Key words: New record, Neoactumnus convexus, Lybia caestifera, Atergatopsis germaini, Platypodia tomentosa, Decapoda, Korean fauna

\section{INTRODUCTION}

Pilumnids are small cryptic crabs living under the rocks, in the crevices or in coral. Most members have the dense grooves and fringes of hair on the carapace and legs. Seven genera of Pilumnidae, Actumnus Dana, 1851, Benthopanope Davie, 1989, Echinoecus Rathbun, 1894, Harrovia Adams and White, 1849, Heteropilumnus De Man, 1989, Pilumnopeus A. Milne-Edwards, 1867, and Pilumnus Leach, 1815, have been recorded in Korean fauna. Genus Neoactumnus consists of Neoactumnus convexus Sakai, 1965 and N. unispina Garth and Kim, 1983 in the world. Neoactumnus convexus has been only reported from southern coast of Japan so far (Sakai, 2004). Neoactumnus convexus is newly reported from Korean fauna.

Many members of xanthids are compact and have the black coloured fingers. More species appear in the Indo-West Pacific than any other sea areas and are found intertidal or subtidal zone. They hide under the rocks or in the sponges and other sessile invertebrates and graze on algae or on detritus. In Korean fauna, sixteen genera of family Xanthidae, Actaea De Haan, 1833, Atergatis De Haan, 1833, Banareia A. Milne-Edwards, 1869, Calvactaea Ward, 1933, Cycloxanthops Rathbun, 1897, Forestia Guinot, 1976, Gaillardiellus Guinot, 1976, Leptodius A. Milne-Edwards, 1834, Macromedaeus Ward, 1942, Medaeops Guinot, 1967, Microcassiope Guinot, 1967, Nanocassiope Guinot, 1967, Neoliomera Odhner, 1925, Novactaea Guinot, 1976, Palapedia Ng, 1993,

\footnotetext{
*To whom correspondence should be addressed

Tel: 82-2-880-6695, Fax: 82-2-872-1993

E-mail: wonkim@plaza.snu.ac.kr
}

and Pilodius Dana, 1851, have been recorded. Three xanthid crabs, Lybia caestifera (Alcock, 1898), Atergatopsis germaini A. Milne-Edwards, 1865, and Platypodia tomentosa (De Man, 1902), is newly recorded in Korean fauna.

Materials examined in this study are deposited in "Depository Bank of Marine Arthropods", Seoul National University. The abbreviation "cl" and "cw" refer to the carapace length from the front to the posterior dorsal margin of the carapace and to the width of the carapace measured at the widest part, respectively. The abbreviated terminology used for carapace regions mostly follows those of Serène (1984).

\section{SYSTEMATIC ACCOUNTS}

Superfamily Pilumnoidea Samouelle, 1819

Family Pilumnidae Samouelle, 1819

Subfamily Pilumninae Samouelle, 1819

Genus ${ }^{1}$ Neoactumnus Sakai, 1965

2*Neoactumnus convexus Sakai, 1965 (Fig. 1)

Neoactumnus convexus Sakai, 1965a, p. 105, fig. 4; Sakai, 1965b, p. 153, fig. 18; Takeda and Koyama, 1974, p. 114, pl. 11D; Sakai, 1976, p. 498, figs. 267a-c; Miyake, 1983, p. 133, fig. 3; Muraoka, 1998, p. 45.

Material examined. 1 우 (cl $9.4 \mathrm{~mm}, \mathrm{cw} 12.6 \mathrm{~mm})$, Munseum (Jejudo Is.), 19 Sept. 1995 (H.S. Kim).

Diagnosis. Carapace (Fig. 1A) nearly as long as wide; dorsal surface strikingly convex in middle, smooth, with indistinct grooves, and covered with velvety tomentums; front (Fig. 1C) wide without median emargination and lateral

$1 *$ 민이마부채게속 (신칭), ${ }^{2 *}$ 민이마부채게 (신칭) 

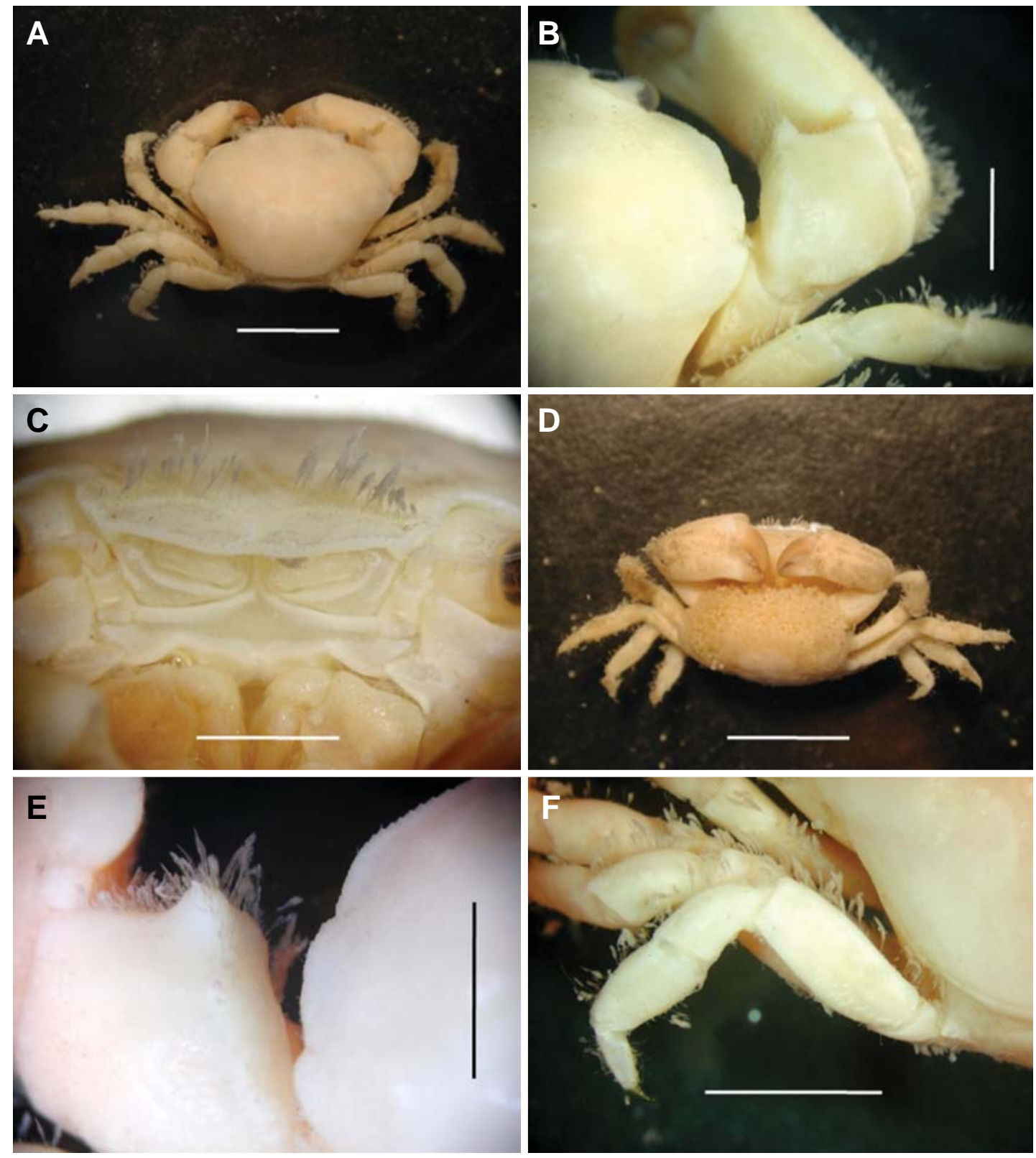

Fig. 1. Neoactumnus convexus, Female. A, dorsal view; B, right anterolateral carapace; C, frontal view; $D$, ventral view; $E$, inner carpus of left cheliped; $F$, left $4^{\text {th }}$ ambulatory leg. Scale bars=5 mm (A, D), $1.5 \mathrm{~mm}(B), 2.5 \mathrm{~mm}(C), 3 \mathrm{~mm}(E), 4 \mathrm{~mm}(F)$.

lobule; frontal margin with transverse row of sparse hairs interrupted medially; anterolateral border (Fig. 1B, E) with four lobes including postorbital one; these lobes low-triangular in shape, each separated by very shallow sinus; posterolateral border almost as long as anterolateral one, slightly concave, with no accommodate concavity for fourth ambulatory leg. Orbits circular; preobital and supraobital margin entirely continuous with frontal margin, without preorbital hiatus, bearing indistinct notch near outer orbital tooth. Basal antennal segment not touching ventral prolongation from lateral front; antennal hiatus thin, loosely filling.

Chelipeds (Fig. 1A, D) slightly asymmetrical; carpus and propodus massive; inner corner of carpus armed with tooth and accessory lower tooth; propodus with longitudinal rows of tiny granules on upper and outer surfaces; fingers not gaping very much, not hallowed at tip.

Ambulatory legs (Fig. 1A, D, F) slender; merus, carpus and propodus not much depressed; dactylus sharply hooked 

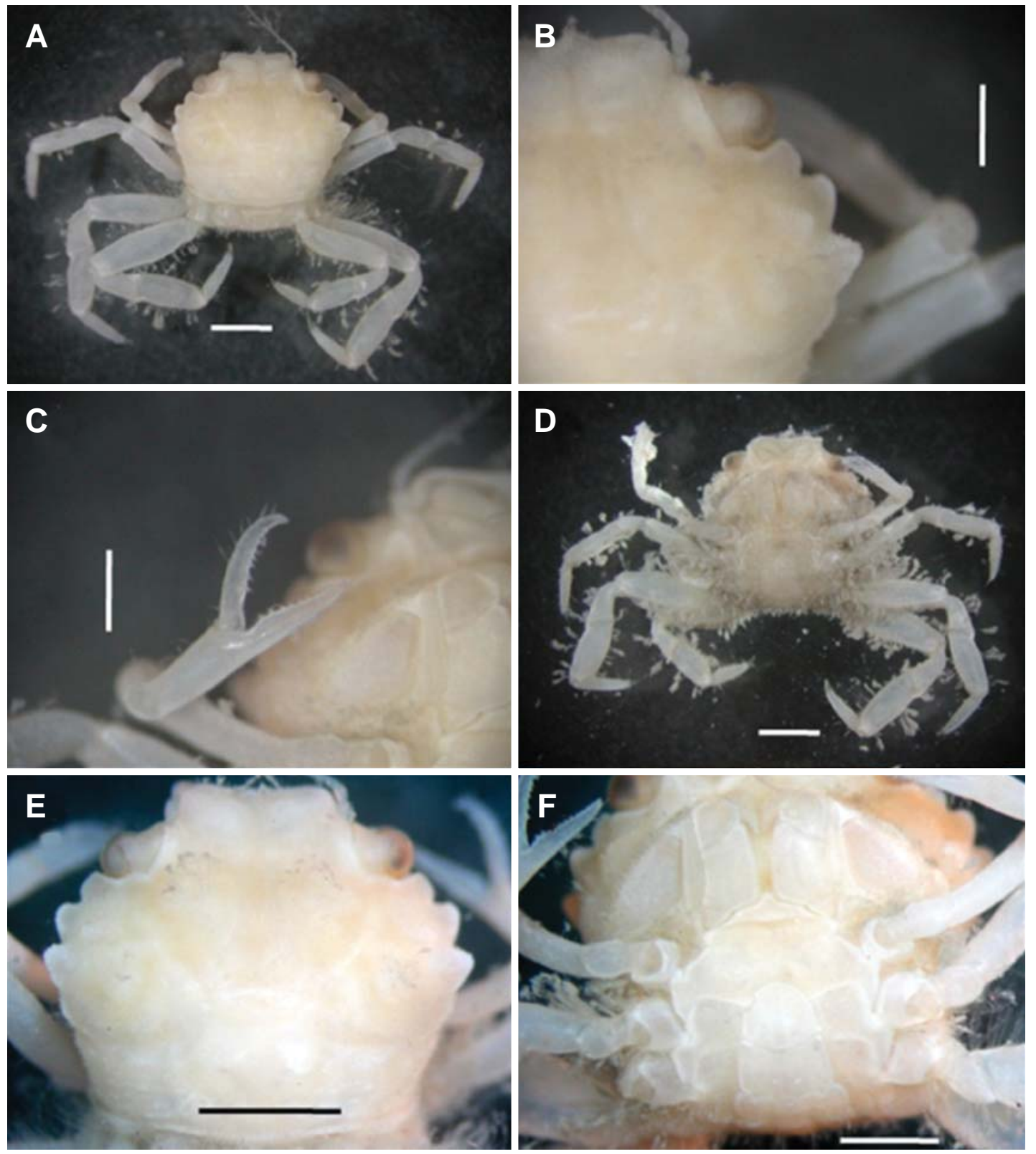

Fig. 2. Lybia caestifera, Female. $A$, dorsal view; $B$, right anterolateral carapace; $C$, right outer chelipe; $D$, ventral view; $E$, surface of carapace; F, abdominal view. Scale bars $=2 \mathrm{~mm}(A, D), 1.5 \mathrm{~mm}(B, C, E), 0.6 \mathrm{~mm}(F)$.

at tip.

Remarks. The carapace of this species is smooth, convex and with no furrows. However, Korean specimen is strikingly convex with indistinct grooves in the middle. The teeth on anterolateral borders are very low triangular in shape so it looks like more circular. Neoactumnus convexus Sakai, 1965 is very similar to N. unispira Garth and Kim, 1983. However, $N$. convexus differs from $N$. unispira in having two fissures on supraobital border and having a spine at the inner angle of the carpus. $N$. convexus has been only recorded in southern coast of Japan (Sakai, 2004). This species is newly reported from Korean fauna and discovered outside the Japanese waters.

Habitat. Bottom of rocks or sand, and on a sea anemone, 25 to $45 \mathrm{~m}$ depth.

Distribution. Japan (Sagami Bay, Kii Nagashima and Kii Minabe), Korea (Munseum Is.). 

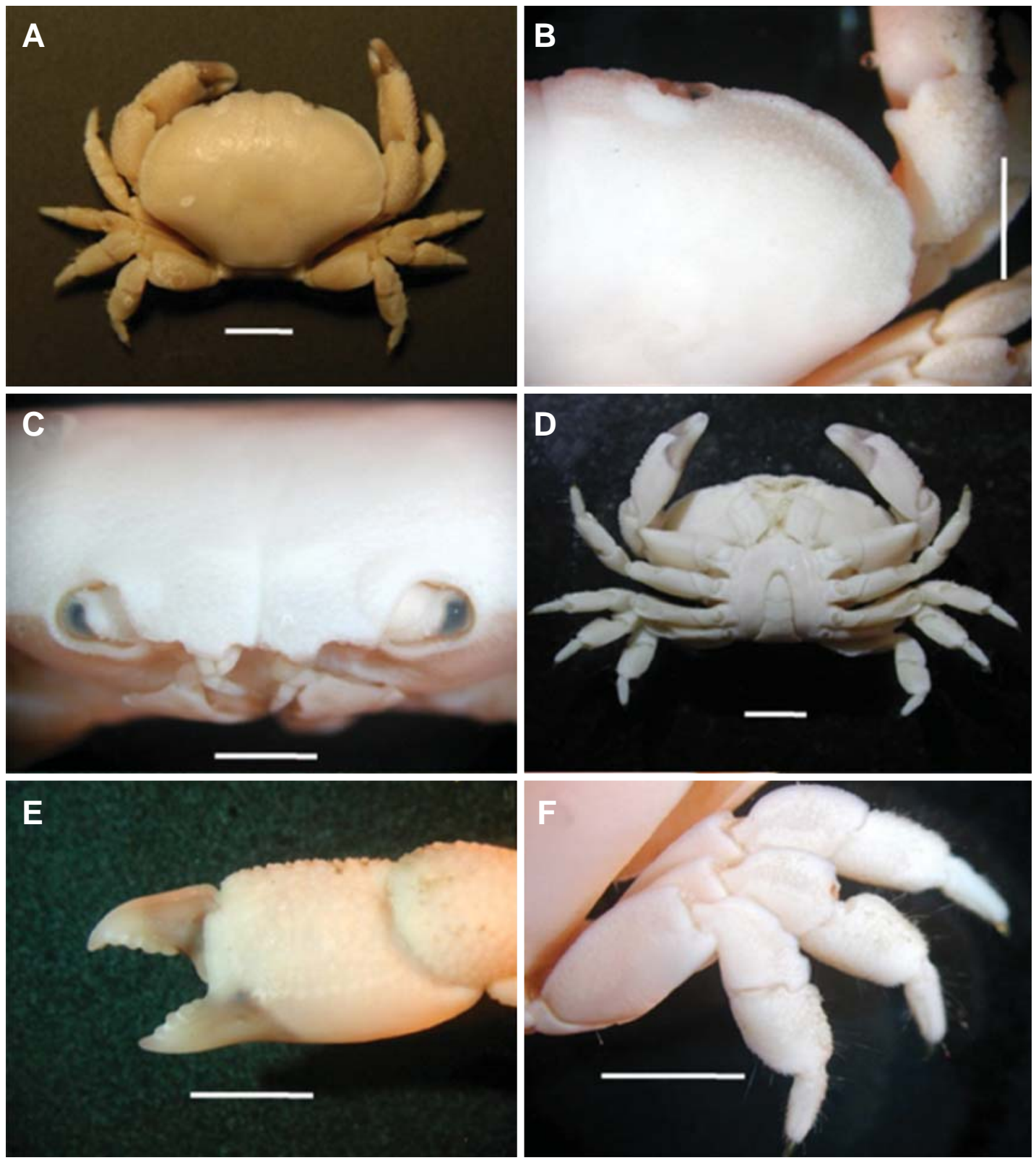

Fig. 3. Atergatopsis germaini, 1865, Male. A, dorsal view; $B$, right anterolateral carapace; $C$, frontal view; $D$, whole animal ventral view; $E$, outer view of left cheliped; $F$, right $4^{\text {th }}$ ambulatory leg. Scale bars $=5 \mathrm{~mm}(A, D), 3 \mathrm{~mm}(B, E), 2 \mathrm{~mm}(C), 4 \mathrm{~mm}(F)$.

Superfamily Xanthoidea MacLeay, 1938

Family Xanthidae MacLeay, 1838

Subfamily Polydectinae Dana, 1851

Genus ${ }^{1 *}$ Lybia H. Milne Edwards, 1834

${ }^{2}$ Lybia caestifera (Alcock, 1898) (Fig. 2)

Melia caesifer Alcock, 1898, p. 231.

Lybia caestifera: Sakai, 1976, p. 504, pl. 180, fig. 2; Guinot, 1976, p. 75, pl. 19, fig. 5; Miyake, 1983, p. 128, pl. 43, fig. 6; Serène, 1984, p. 25 (list); Takeda, 1989, p. 161; Dai and Yang, 1991, p. 379, pl. 51 (2).

Material examined. 1 우 (cl $3.6 \mathrm{~mm}$, cw $4.0 \mathrm{~mm}$ ), Munseum (Jejudo Is.), 6 June 2001 (S.H. Kim).

Diagnosis. Carapce (Fig. 2A, E) subhexangular, uneven, and less areolated; front broad, relatively straight anterior margin without median notch, cutting into 2 lobes by longitudinal

\footnotetext{
$1 *$ 가는손부채게속 (신칭), ${ }^{2 *}$ 가는손부채 게 (신칭)
} 

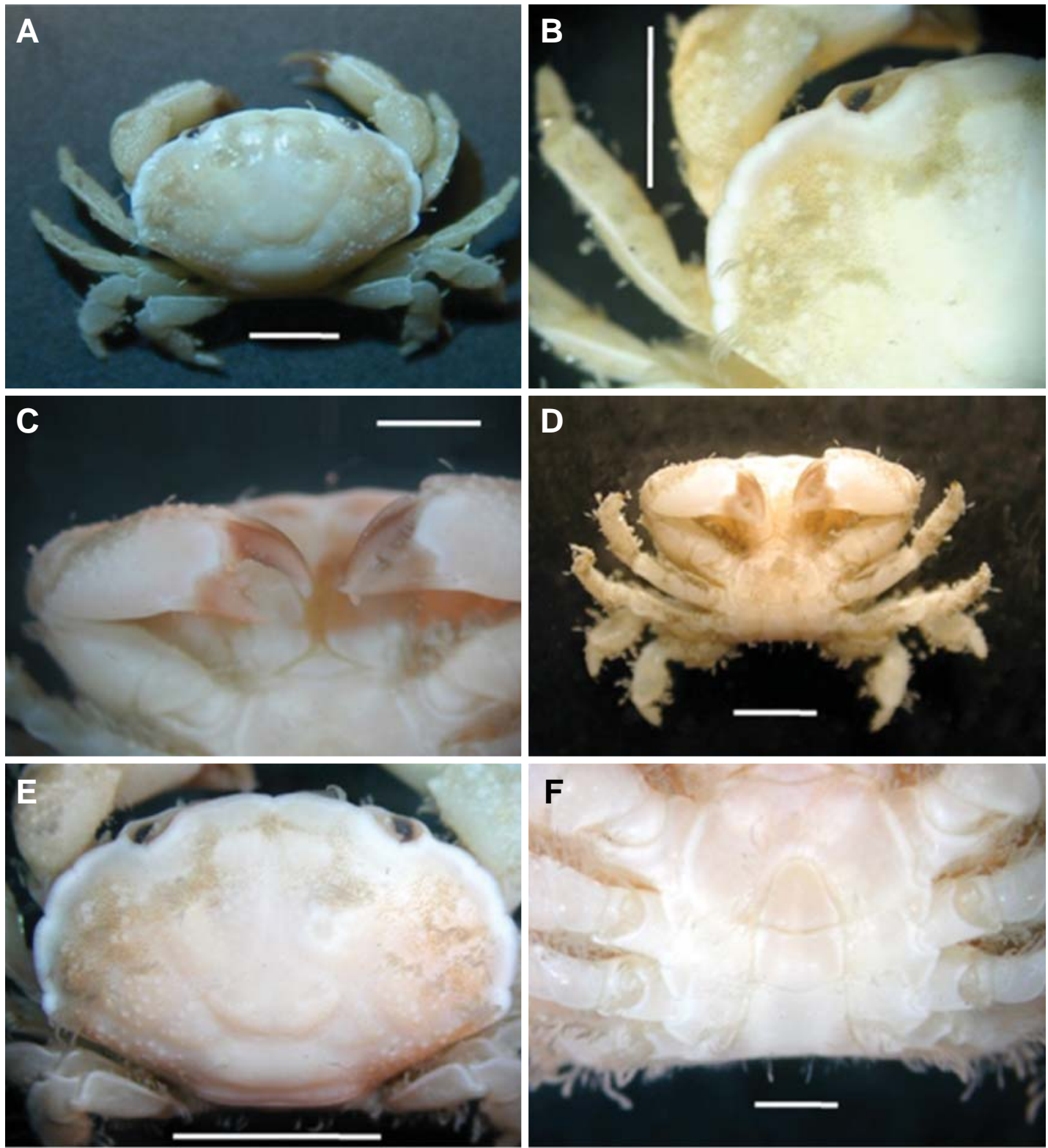

Fig. 4. Platypodia tomentosa, Male. $A$, whole animal dorsal view; $B$, left anterolateral carapace; $C$, outer chelipeds; $D$, ventral view; E, surface of carapace; F, abdominal view. Scale bars=3 mm (A, D, E), $2 \mathrm{~mm}(B), 1.5 \mathrm{~mm}(C), 1 \mathrm{~mm}(F)$.

median trace with each lobes separated from innerorbital tooth by slanting mark; anterolateral border (Fig. 2B) armed with no serrated, triangular three teeth; third tooth rudimentary. Both sides of $1 \mathrm{~F}, 2 \mathrm{M}$, and $4 \mathrm{~L}$ of carapace with small bundles of setae.

Chelipeds (Fig. 2C) very slender and small; fingers quite slim with tip curved and claw-shaped, bearing acute on teeth both inner margins.

Ambulatory legs (Fig. 2A, D) relatively stouter than chelipeds, with few setae on upper and inner borders; dactyli with small, few teeth, and quite sharp at tip. Forth pair of ambulatory leg shorter and smaller than others.

Female abdomen (Fig. 2D, F) elongated.

Remarks. Korean specimen is agreed well with Dai and Yang (1991)'s description but carapace of Korean specimen has relatively small lobes on the frontal margin and no small bundles of setae on both sides $2 \mathrm{P}$.

Habitat. Coral reefs in shallow waters.

Distribution. Red Sea, Indo-West pacific, Japan, Taiwan, Hawaii, Tahiti, Korea. 
Subfamily Zosiminae Alcock, 1898

Genus ${ }^{1 *}$ Atergatopsis A. Milne-Edwards, 1862

2*Atergatopsis germaini A. Milne-Edwards, 1865

(Fig. 3)

Atergatopsis germaini A. Milne-Edwards, 1865, p. 257, pl. 11, figs. 1a-b; Guinot, 1964, p. 16, figs. 3a-c; Sakai, 1976, p. 413 , fig. 217 ; Miyake, 1983, p. 103, pl. 35, fig. 2 ; Serène, 1984, p. 141.

Material examined. $1 \sigma^{\nearrow}(\mathrm{cl} 9.3 \mathrm{~mm}, \mathrm{cw} 14.7 \mathrm{~mm})$, Hongdo Is. (Gyeongsangnam-do), 20 May 1978 (H.S. Kim).

Diagnosis. Carapace (Fig. 3A) naked, carmine coloured, covered with fine granular surfaces, convex in middle, and hemispherical in outline; each region obscurely defined and markedly convex in 2F; anterolateral margin (Fig. 3B) conspicuously with three oblique teeth, lined with fine studded granules; anterolateral borders not crested; front (Fig. 3C) smooth, one third to carapace width, cutting into two lobes by longitudinal median trace.

Chelipeds (Fig. 3A, D, E) with relatively long fingers; fingers blunt, black coloured at their apices with one row of four oblique teeth, hardly projecting; upper part of palm granular and lower part smooth.

Ambulatory legs (Fig. 3A, D, F) granular at surface, little depressed, and subcylindrical.

First gonopods very slender, inner curved, with four bristles on distal end.

Remarks. Atergatopsis germaini has three teeth on the inner immovable fingers (Sakai, 1976) but the present specimen has four teeth. Upper part of movable fingers have two grooves due to longitudinal median crest, and dorsal surface of carapace has indistinct furrows.

Habitat. Coral reef, shallow waters.

Distribution. Japan, Taiwan, The Philippines, Vietnam, New

Guinea, Korea.

Family Xanthidae Macleay, 1838

Subfamily Zosiminae Alcock, 1898

Genus ${ }^{3 *}$ Platypodia Bell, 1835

4*Platypodia tomentosa (De Man, 1902) (Fig. 4)

Lophactaea tomentosa De Man, 1902, p. 585.

Platypodia tomentosa: Buitendijk, 1941, p. 309, fig. 3C; Sakai, 1983, p. 15, pl. 2, fig. 4; Serène, 1984, p. 157.

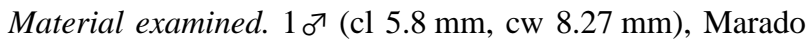
Is., 4 Nov. 2000 (S.H. Kim).

Diagnosis. Carapace (Fig. 4A, E) granular, covered with short brown tomentum and semicircular in outline; each hepatic region and protogastric region ornamented with bundles of long hair; each regions of carapace separated by feeble furrow; $1 \mathrm{~F}$ and $2 \mathrm{~F}$ conjugated, $1 \mathrm{M}$ convex, and $2 \mathrm{M}$ not divided into two pars longitudinally; anterolateral borders (Fig. 4B) well crested, and divided into four blunt lobes with indistinct notch between them.

Chelipeds (Fig. 4C) well developed, black coloured at their apices; superior margin of palm with smooth crest along whole length; outer palm with small granules and few setae. Immovable fingers blade-like with strong trifid tooth proximally.

Ambulatory legs (Fig. 4A, D) very depressed, with few setae on upper and lower border; infra-border of merus with crest.

Remarks. In Korean specimen, the lobes of anterolateral margin are asymmetrical and the notches between lobes are irregular along outline of the carapace. This specimen has no bundle of long hair on the cardiac region and $2 \mathrm{M}$ region is not divided by furrow longitudinally.

Habitat. In the crevices and on the coral reef.

Distribution. Red sea, Madagascar, Japan, China, Taiwan, Australia, Hawaiian Islands, Korea.

\section{ACKNOWLEDGEMENTS}

This work was supported by a grant (No. 2006-421) from the Ministry of Environment of the Korean Government and Korean Research Foundation Grant (KRF-2005-070-C00124).

\section{REFERENCES}

Alcock, A.W., 1898. Materials for a carcinological fauna of India. No. 3. The Brachyura Cyclometopa. Part 1. The family Xanthidae. J. Asiatic Soc. Bengal, 67, part 2(1): 67-233.

Buitendijk, A.M., 1941. Biological results of the Snellius Expedition. XIII. On some Xanthidae, chiefly of the genus Platypodia Bell. Temminkia, 6: 295-312.

Dai, A.Y. and S.L. Yang, 1991. Crabs of the China Seas. Springer-Verlag, Berlin, Heidelberg, New York, Tokyo, pp. 1608.

De Man, J.G., 1902. Die von Herrn Professor Kükenthal im indischen Archipel gesammelten Dekapoden und Stomatopoden. In Kükenthal, W., ed., Ergebnisse Einer Zoologichen Forschunsreise in den Molukken und Borneo, in Aufträge der Senckenberg. Naturforsch. Gesllschaft ausgeführt von Dr. Willy Kükenthal. Abhandlungen der Senckenbergischen naturforschenden Gesellschaft, 25(3): 465-929.

Guinot, D., 1964. Crustacés Décapodes Brachyoures (Xathidae) des campagnes de la Calypso en Mer Rouge (1952), dans le Golfe Persique et a l'île Aldabra (1954). Mém. Mus. Hist.

$1 *$ 고운반달게속 (신칭), ${ }^{2 *}$ 고운반달게 (신칭), ${ }^{3 *}$ 납작발부채게속(신칭), ${ }^{4 *}$ 납작발부채게 (신칭) 
Nat., Paris, Sér. A, 32: 1-108.

Guinot, D., 1976. Constitution de quelques groups naturels chez les Crustacés Décapodes Brachyoures. I. La superfamille des Bellioidea Dana et trios sous-familles de Xathidae (Polydectinae Dana, Trichiinae de Haan, Actaeinae Alcock). Mém. Mus. Hist. Nat., Paris, Sér. A, 97: 1-308.

Milne-Edwards, A., 1865. Études zoologiques sur les Crustacés récents de la famille des Cancériens. Cancérides, Pirmélides, Carpilides, Première Partie. Nouv. Archives Mus. Hist. Nat., Paris, 1: 177-308.

Miyake, S., 1983. Japanese crustacean decapods and stomatopods in color. Hoikusha Publishing Co. Ltd., 2: 1-277.

Muraoka, K., 1998. Catalogue of the brachyuran and anomuran crabs donated by Prof. Dr. Tune Sakai to the Kanagawa Prefectural Museum. Cat. Coll. Kanagawa Pref. Mus. Nat. Hist., 11: 5-67.

Sakai, K., 2004. Crabs of Japan. World biodiversity database CD-ROM series.

Sakai, T., 1965a. On two new genera and five new species of xanthoid crabs from the collection of his majesty, the emperor of Japan made in Sagami Bay. Crustaceana, 8(1): 97-
106.

Sakai, T., 1965b. The Crabs of Sagami Bay, collected by his majesty the emperor of Japan. Muruzen co., Tokyo, pp. 1206 (In English), pp. 1-92 (In Japanese).

Sakai, T., 1976. Crabs of Japan and the adjacent Seas. Kodansha Ltd., Japan, pp. 1-773.

Sakai, T., 1983. Description of a new genera and species of Japanese crabs, together with systematically and biogeographically interesting species. Res. Crustacea, 12: 1-44.

Serène, R., 1984. Crustacés Décapodes Brachyoures de l'Océan Indian Occidental et de la Mer Rouge, Xanthoidea: Xanthidae et Trapeziidae. Avec un addendum par Crosnier, A.: Carpiliidae et Menippidae. Faune Tropicale, 24: 1-349.

Takeda, M. and K. Koyama, 1974. On some rare crabs from Kii Province. Res. Crustacea, 6: 103-121.

Takeda, M., 1989. Shallow-water Crabs from the Oshima Passage between Amami-Oshima and Kakeroma-jima Islands, the Northern Tyukyu Islands. Mem. Nat. Sci. Mus., Tokyo, 22: $135-184$.

Received October 24, 2008 Accepted November 13, 2008 